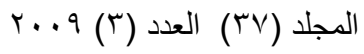
(ISSN $1815-316 \mathrm{X})$
مجلة زر اعة الر افدين

تأثير مواعيل ومستويات الرش بمبيد Galant super بتراكيز مختلفة في مكافحة الحليان

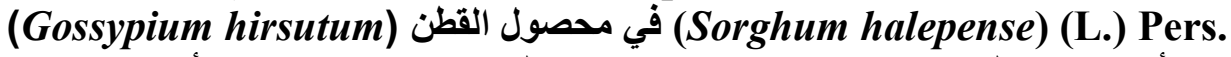

$$
\text { وحدة بحوث أرنطن النعيمي }
$$

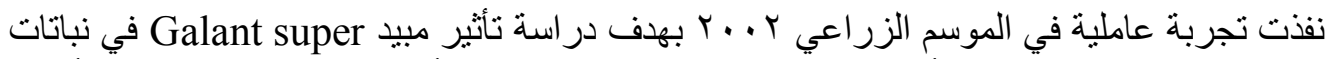

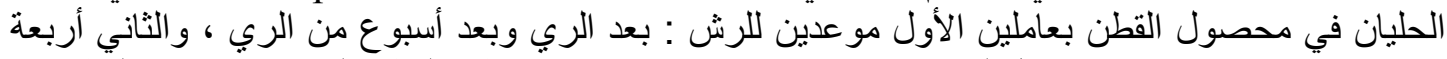

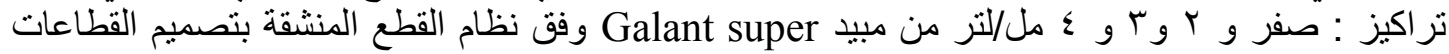

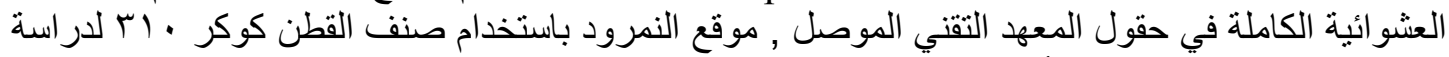

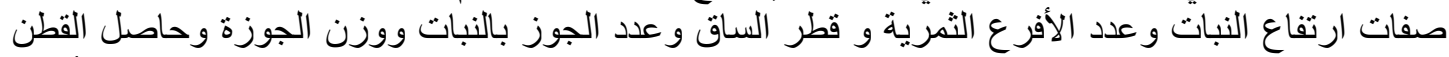

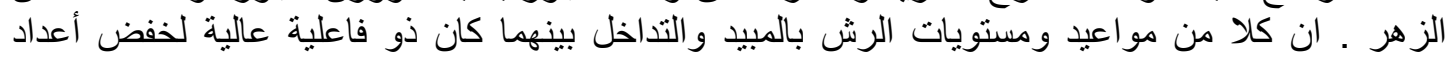

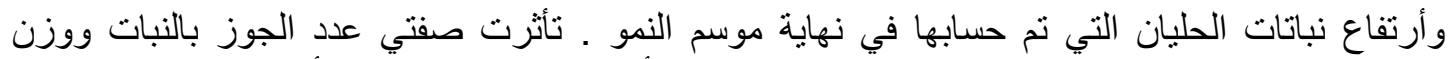

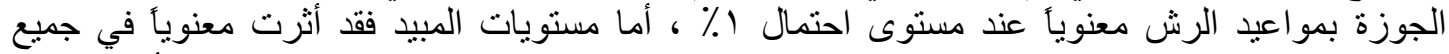

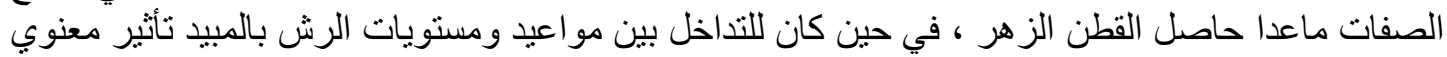

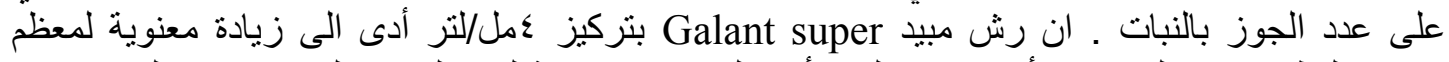

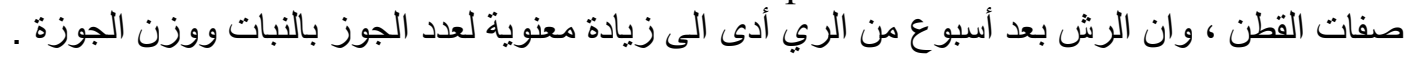

\title{
المقدمة
}

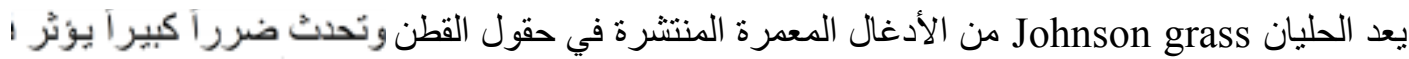

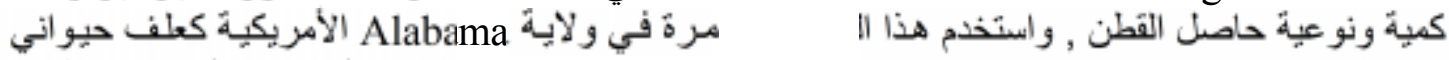

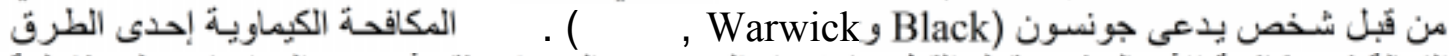

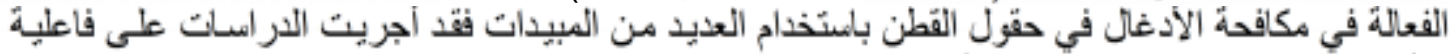
وتأثنير مبيد Galant super على الأدغال المعرة ومن بينها الحليان في حقول القطن بركيز

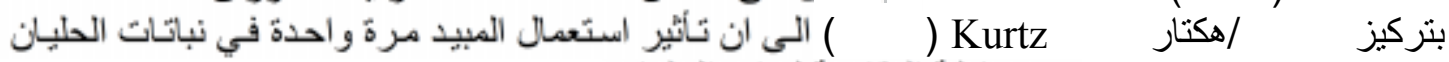

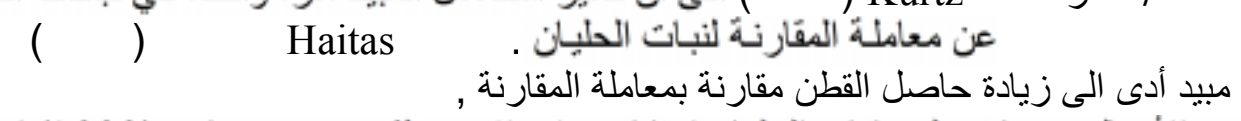

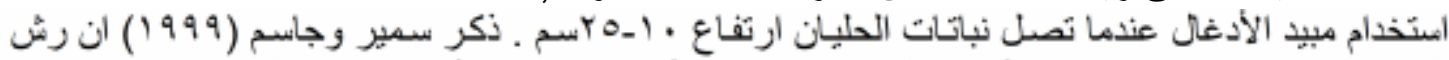

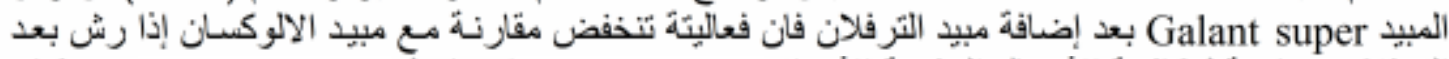

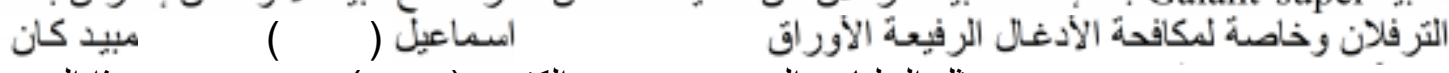

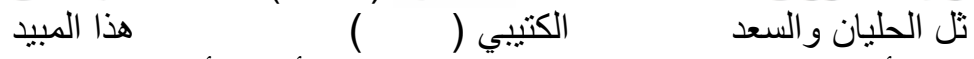

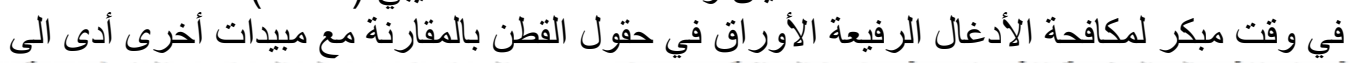

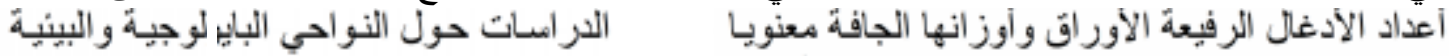

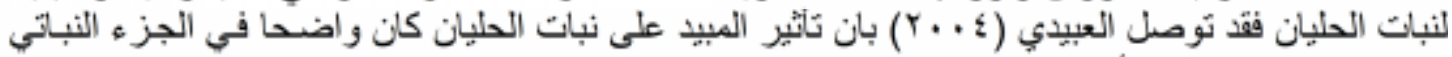

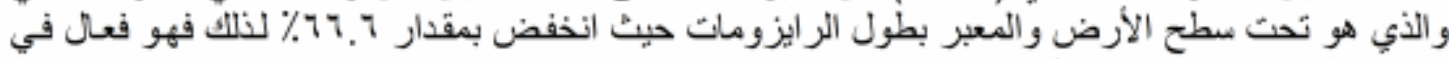

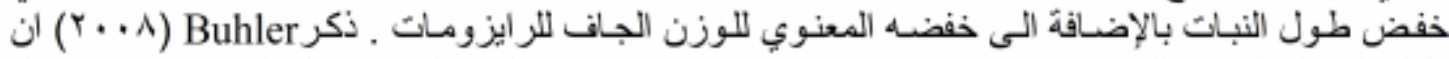

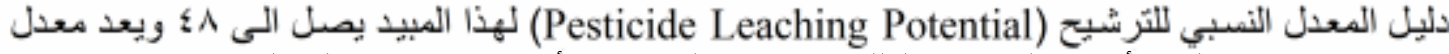

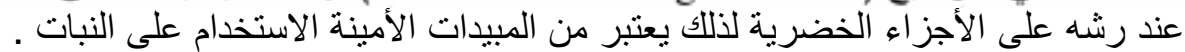

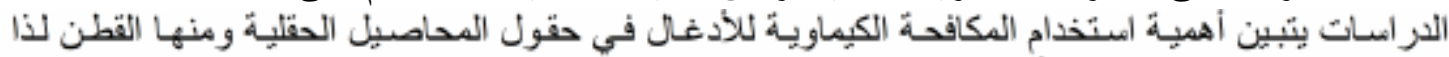

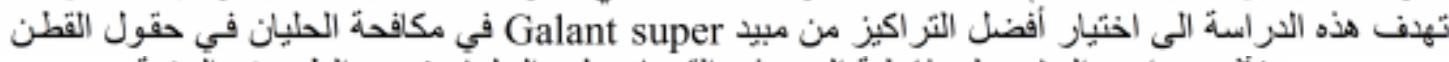

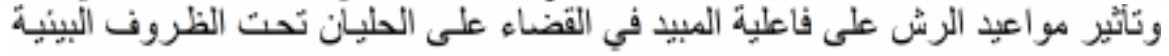

مواد البحث وطرائقه

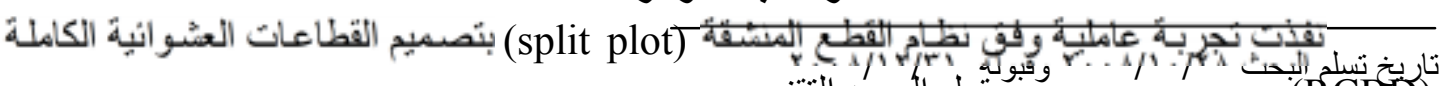
حقول المعهد التقني 
الرئيسة (main plot)

في حقل متُروك بور في السنة السـابقة

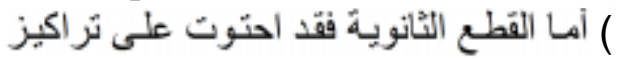

[methyl 2- (4-

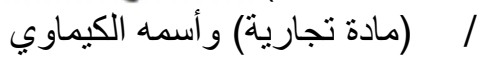

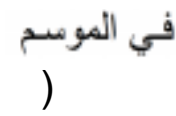

(3-chloro-5-trifluoromethyl)-2-pyridinyl)oxy)phenoxy)pro-panoate]

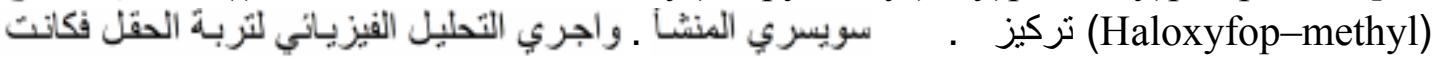

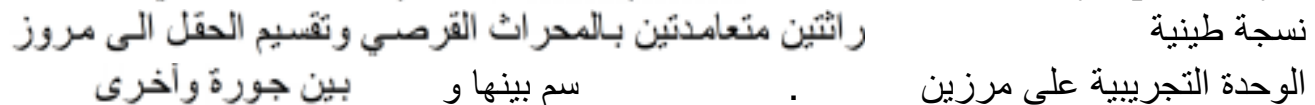

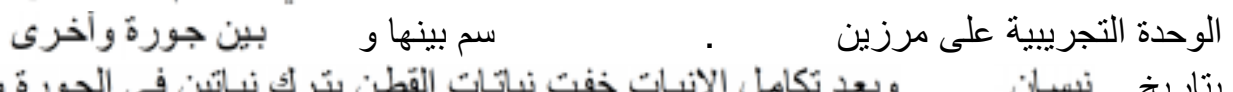

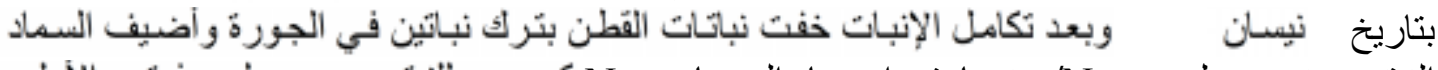

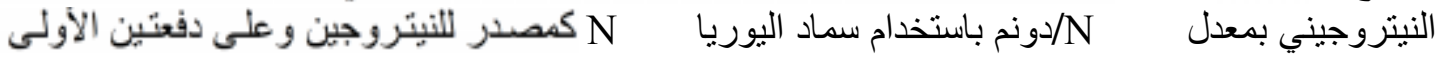

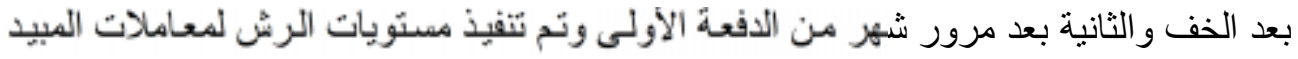

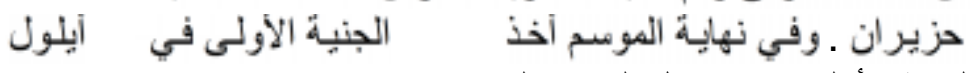

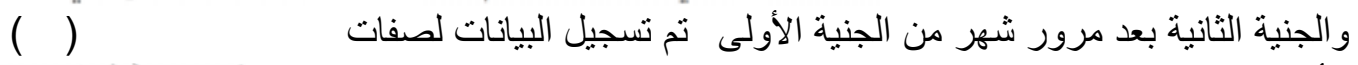

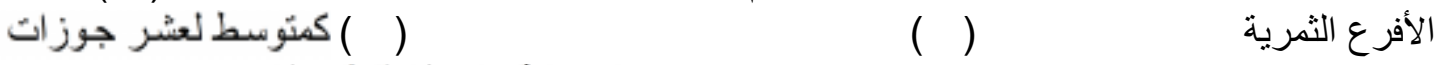

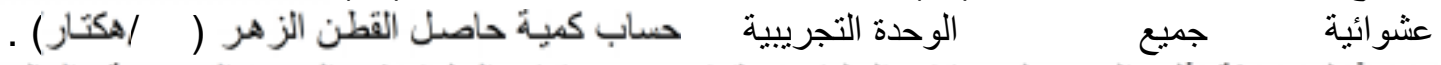

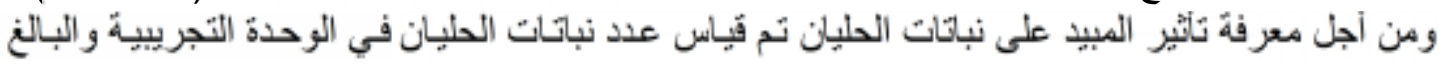

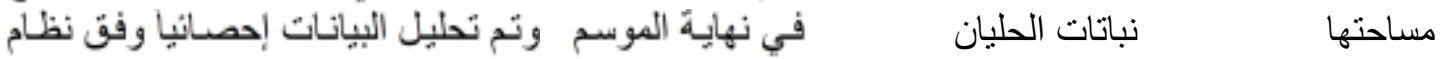

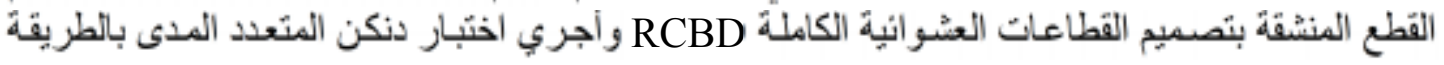
التي أوضحها الراوي وخلف الله ( ) ).

\section{النتائج والمناقثة}

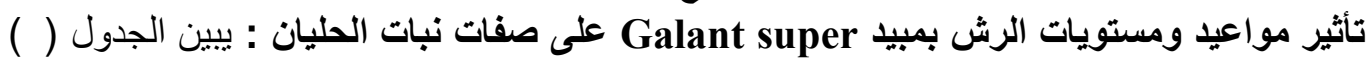

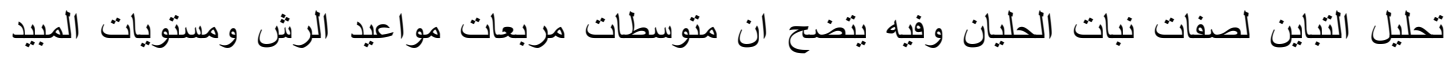

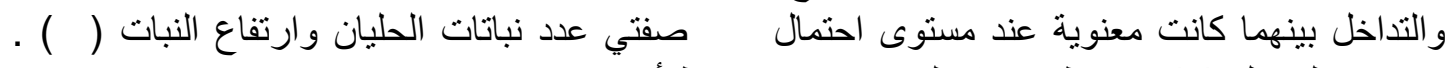
ويوضح الجدول ( ) متوسطات هذه الصفات وفيه نلاحظ أن رش من مبيد

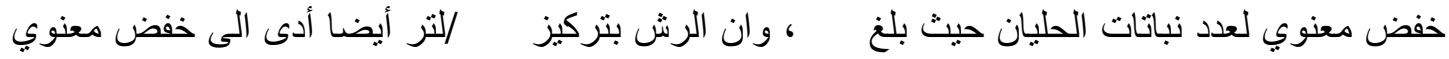

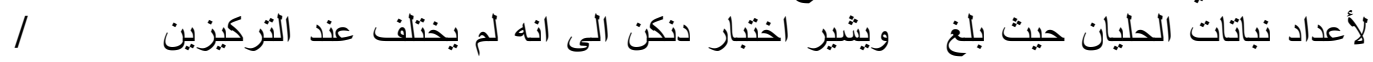

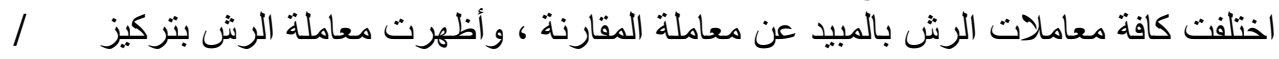

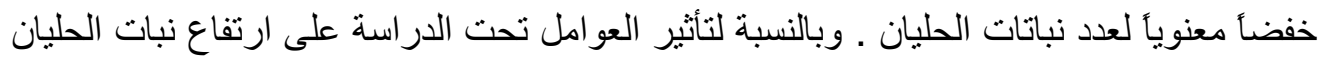

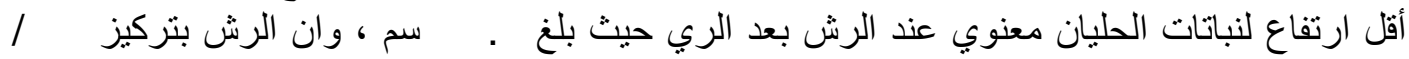

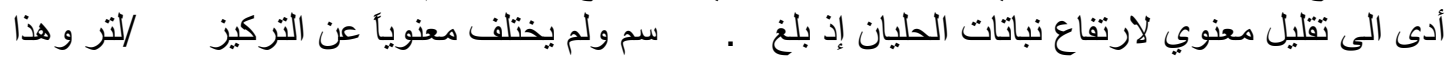

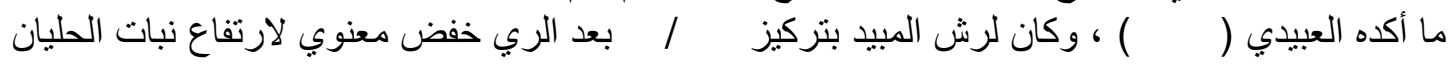

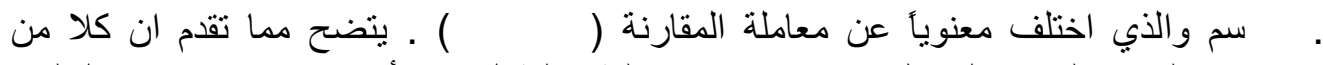

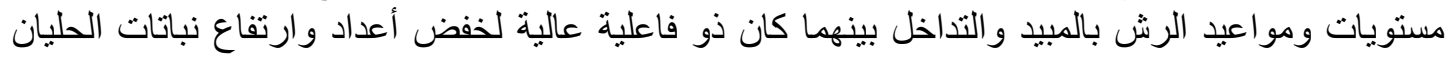

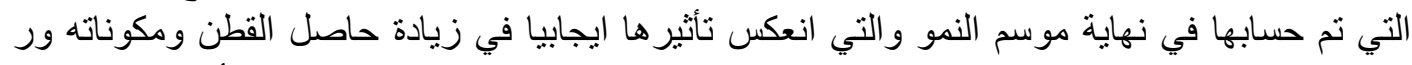

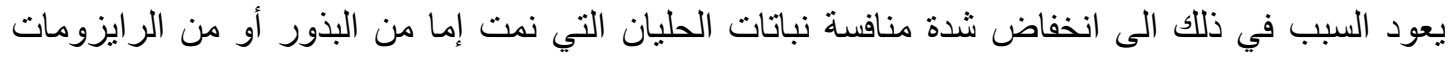

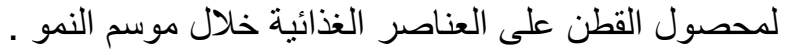



( ) ( )
(ISSN $1815-316 \mathrm{X})$
مجلة زر اعة الر افدين

Gallant super ( ) : تحليل التباين لصفات نبات الحليان عند مستويات ومو اعيد الرش بمبيد .

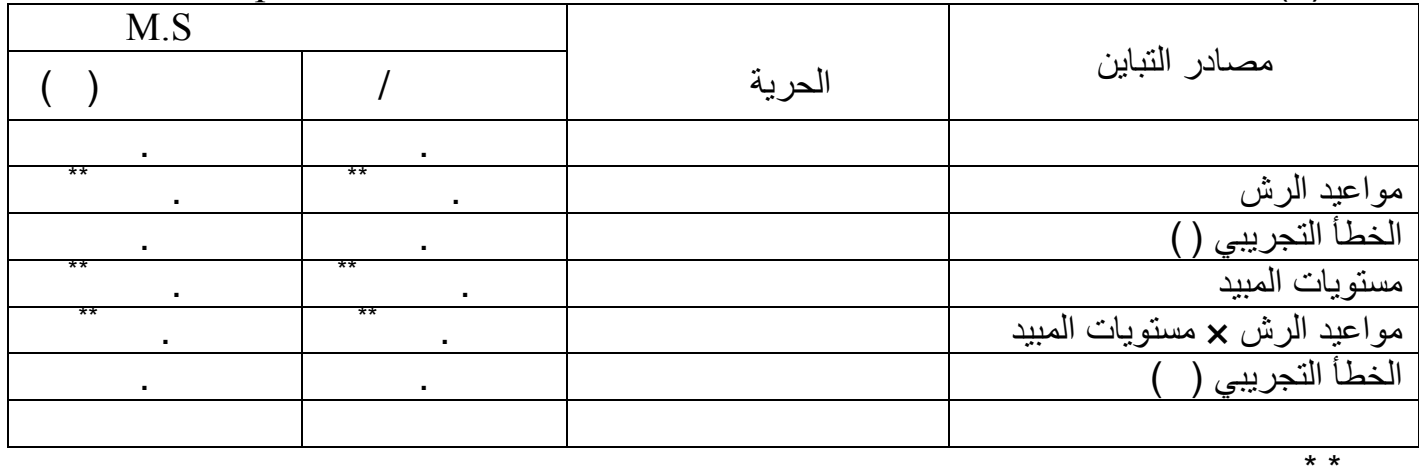

نباتات الحليان .

Gallant super تأثثر مستويات ومو اعبد الرش بمبيد ) ( )

\begin{tabular}{|c|c|c|c|c|c|c|}
\hline \multicolumn{3}{|c|}{()} & \multicolumn{3}{|c|}{ I } & \multirow[b]{2}{*}{ مستويات الرش ( ) ( ) } \\
\hline مستويات & & & مستويات & & & \\
\hline . & . & . & . & . & & \\
\hline . & . & . & . & . & . & \\
\hline . & . & . & . & . & . & \\
\hline . & . & . & . & . & . & \\
\hline & . & . & & . & . & معدل مو اعبد \\
\hline
\end{tabular}

منشابهة لا تختلف عن بعضها معنوياً عند مستوى احتمال

تأثير مواعيد ومستويات الرش بمبيد Galant super على صفات القطن : تشير النتائج المبينة في الجدول

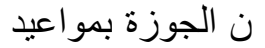

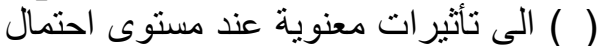

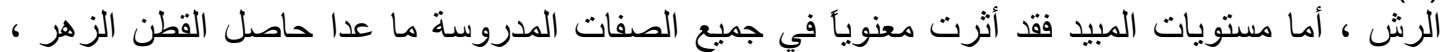

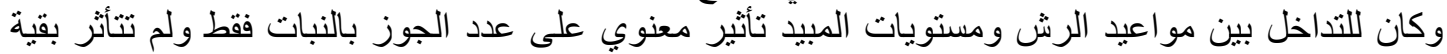
قطر الساق و عدد الأفرع الثمرية وحاصل الترن القطن

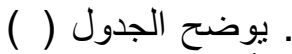

الزهر لم تتأثر معنوياً بموعدي الرش بعد الري والرش بعد أسبوع من الري ، في حين تشير متوسطات

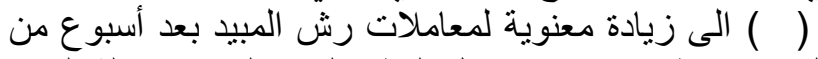

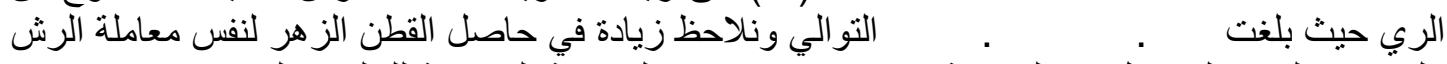

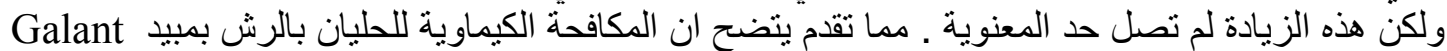

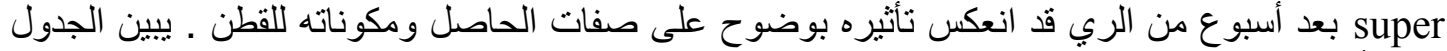

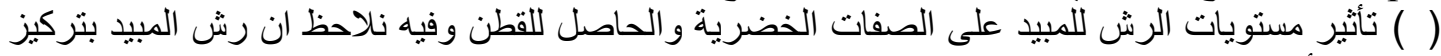

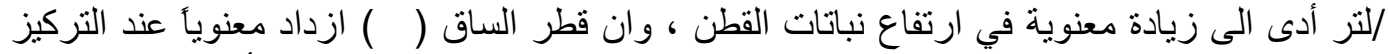

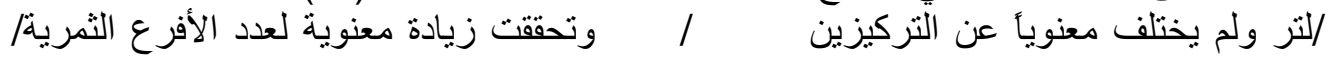

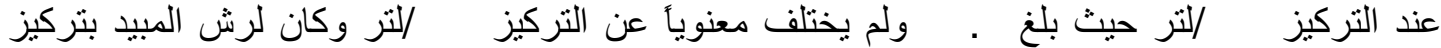

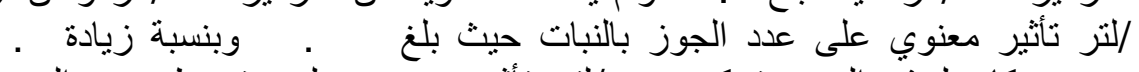

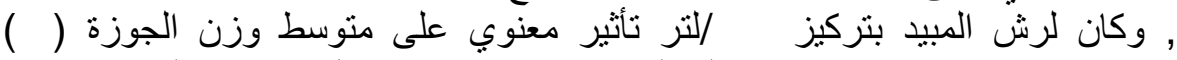

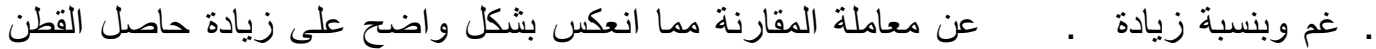

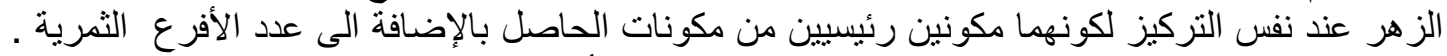

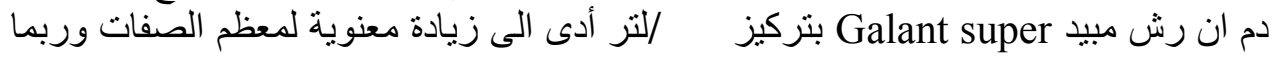

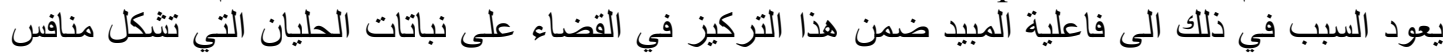

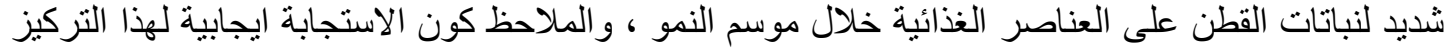

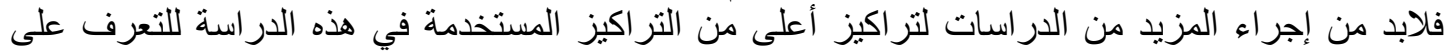



( ) ( )
(ISSN $1815-316$ X)
مجلة زر اعة الر افدين

تأثثرها صفات محصول القطن التي ربما تكون بالاتجاه السلبي وتؤدي الى خسارة في الحاصل وزيادة

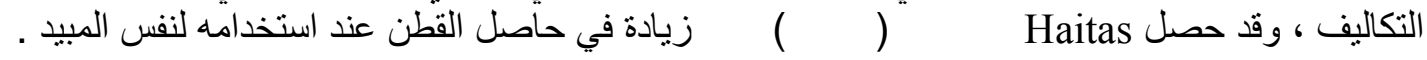

|

\begin{tabular}{|c|c|c|c|c|c|c|c|}
\hline & & & & \multicolumn{4}{|c|}{ بمبيد Galant super . } \\
\hline \multicolumn{6}{|c|}{ M.S } & \multirow[b]{2}{*}{ الحرية } & \multirow[b]{2}{*}{ مصادر التباين } \\
\hline ( الزكتار ) & () & / & الثمرية & $(）$ & $(）$ & & \\
\hline & . & . & . & . & . & & \\
\hline . & . & & . & . & . & & مو اعيد الرش \\
\hline . & . & . & . & . & . & & الخطأ التجريبي ( ) \\
\hline & & ** & & & & & مستويات المبيد \\
\hline · & $\cdot$ & ** & & . & . & & مستويات الرشبيد \\
\hline & . & & & . & . & & التجريبي(ب) \\
\hline & & & & & & & \\
\hline
\end{tabular}

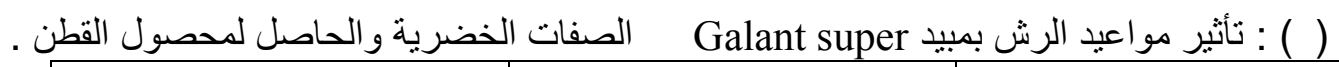

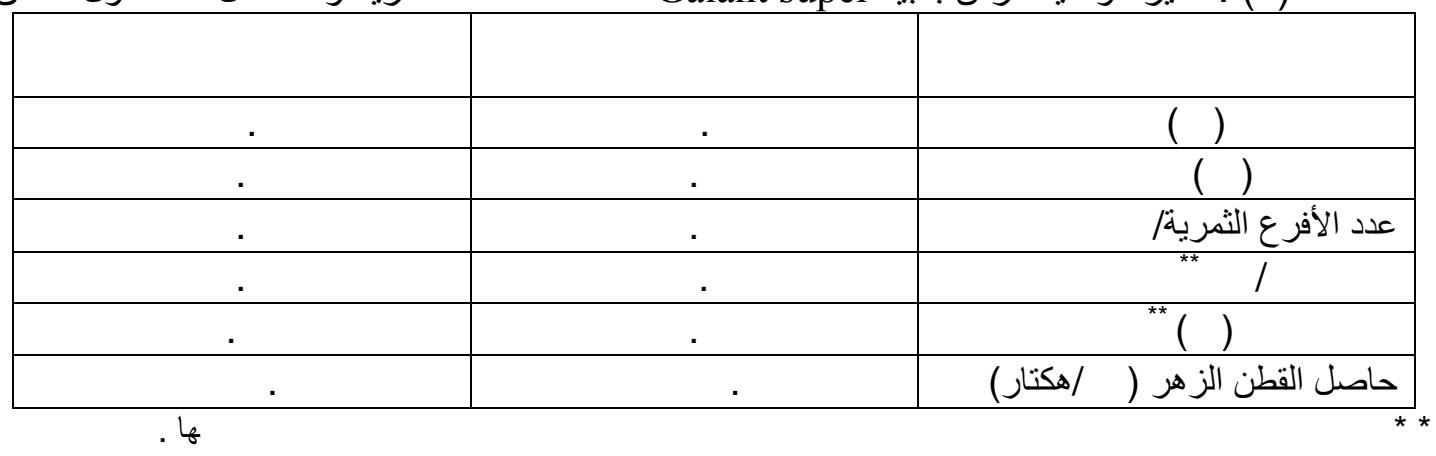

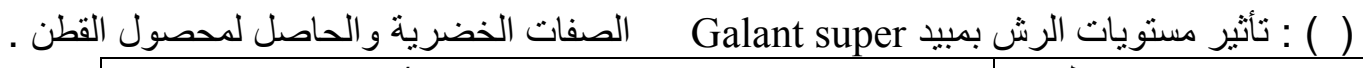

\begin{tabular}{|c|c|c|c|c|}
\hline \multicolumn{4}{|c|}{ / Galant super مبيد } & مستو يات الرش \\
\hline . & . & . & . & () \\
\hline . & . & . & . & ${ }^{\star \star *}(\quad)$ \\
\hline . & . & . &. & عدد الأفرع الثمرية" \\
\hline . & . & . & . & l \\
\hline . & . & . & . & ${ }^{* *}(）$ \\
\hline & & & & حاصل القطن الزهر /هكتار ) \\
\hline
\end{tabular}

بين مو اعيد ومستويات بيد Galant super و تأثثيره على صفات القطن فان

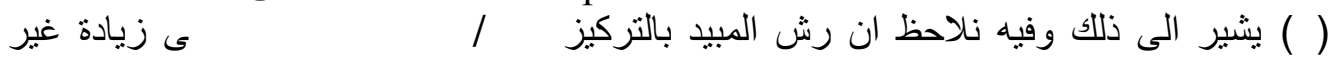



( ) ( )
(ISSN $1815-316 \mathrm{X})$
مجلة زر اعة الر افدين

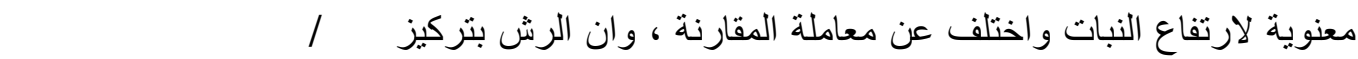

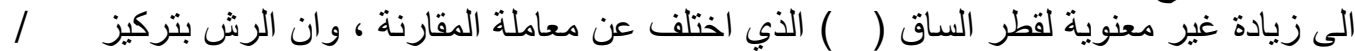

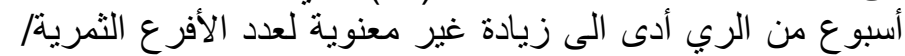

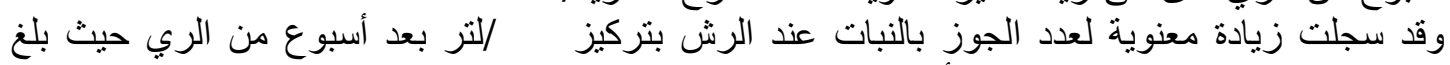

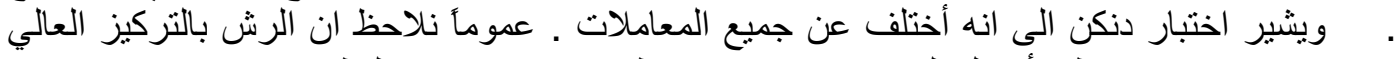

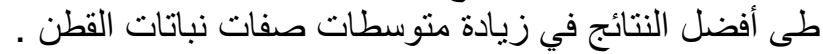

( ) : تأثثير التداخل بين مواعبد مستويات الرش بمبيد Galant super الصفات الخضرية

\begin{tabular}{|c|c|c|c|c|c|c|c|c|c|}
\hline & & & & & & & & & مو اعيد الرش \\
\hline \multicolumn{5}{|c|}{ مبيد Galant super } & \multicolumn{4}{|c|}{ / Galant super مبيد } & مستويات \\
\hline . & & & . & & . & & & . & ( ) \\
\hline . & . & & & . & . & . & & $\cdot$ & ( ) \\
\hline . & . & & . & 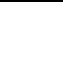 & . & . & & . & / عدد الأفرع الثمرية \\
\hline . & . & $ه$ & & . & . & . & . & . & $\begin{array}{ll}* * & 1\end{array}$ \\
\hline . & . & & . & $\bowtie$ & . & . & . & $\infty$. & () \\
\hline . & & & & & & & $ه$ & . & الزهر ( / هكتار) \\
\hline
\end{tabular}

INFLUENCE OF GALANT SUPER APPLICATION TIME AND RATES IN CONTROL JOHNSON GRASS (Sorghum halepense) (L.) Pers. IN COTTON CROP (Gossypium hirsutum)

Arshad Thanoon Al-Niaumi Ibraheem Mohamed Alyas Hazem Ahmed Kasim Cotton Research Unit

Plant Production Dept.

Plant Production Dept.

Commission of Technical Education /Insti. Tech. Educa. Mosul, Iraq

ABSTRACT

A factorial experiment was conducted in the season 2004 to study the effect of Galant super herbicide for controlling Johnson grass in cotton crop with two factors, the first : two time of application (after irrigation) and after a week of irrigation, and the second four rates $(0,2,3,4 \mathrm{~m} /$ Liter $)$ of herbicide in split plot system with RCBD at the fields of technical institute of Mosul -Al namrood location using Koker-310 variety of cotton to study the characters of plant height, No. of fruiting branches, stem diameter, No. bolls per plant, boll weight and seed cotton yield. Both time and rates of spraying herbicide and the interaction between them had height effect in reducing No. of plant and plant height of Johnson grass which calculated in the end of season. The No. bolls per plant and boll weight affected significantly at $1 \%$ of probability with spraying time, the application rates affected significantly for all characters except seed cotton yield, while the interaction between the two factors had significant effect on No. bolls per plant . Spraying Galant super in concentration $4 \mathrm{ml}$./liter significantly increasing almost all characters of cotton, and spraying after a week of irrigation significantly increasing 

( ) ( )
(ISSN $1815-316 \mathrm{X})$
مجلة زر اعة الر افدين

No. bolls per plant and boll weight which reflects to non significant increasing of seed cotton yield. It's important to study applying higher concentrations of this herbicide in controlling Johnson grass in cotton fields in future .

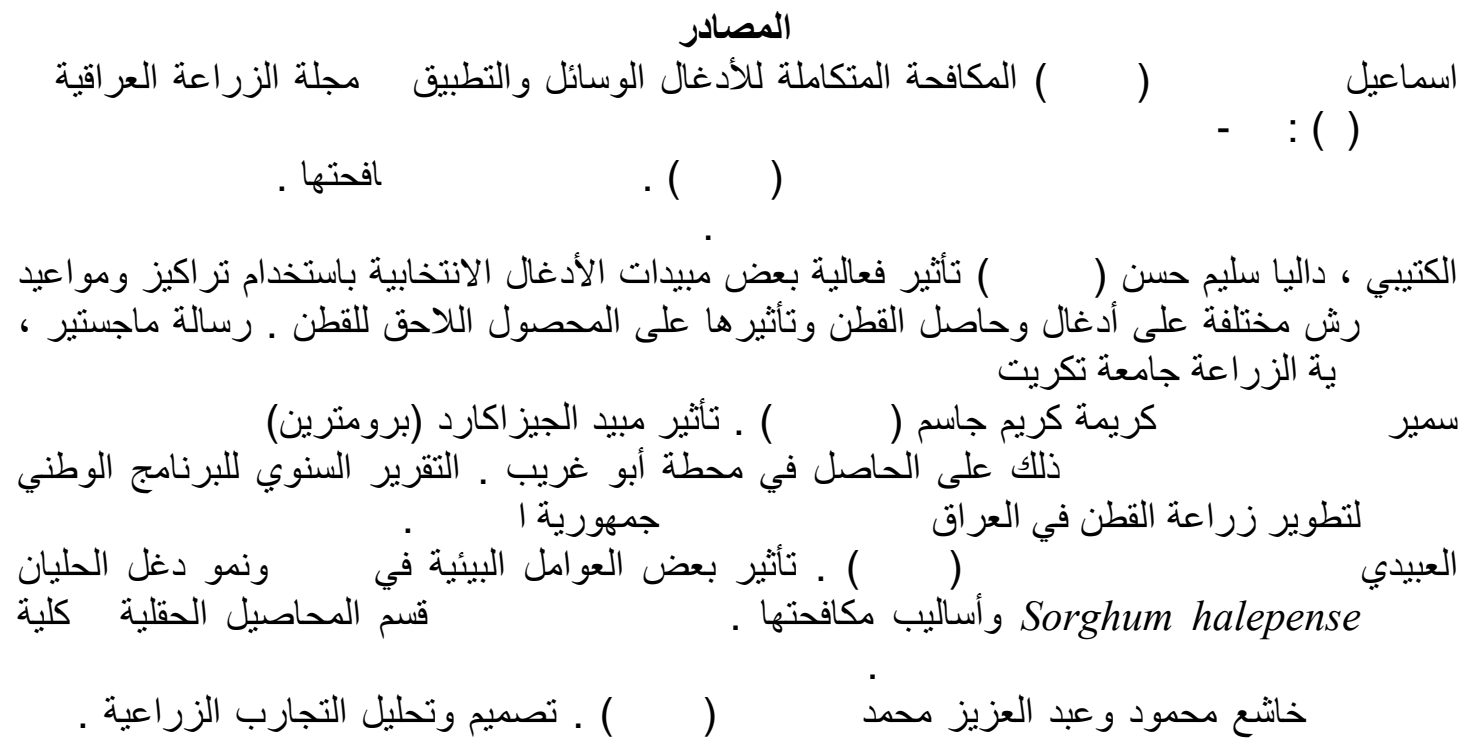

Black , L.D. and S.I. Warwick (1983). The biology of Canadian weeds. 61. Sorghum halepense (L.) pers. Canadian J. of Plant Sci. 63 (4) : 997 - 1014.

Buhler, W. (2008) . Chapter I-Pesticide use and safety information . North Carolina Agricultural Chemicals Manual, the safe use of pesticides, College of Agriculture and Life Sciences, NC State University .

Douglas, D. B. and C. Borvin (1984). Effect of application factors of postemergence phytotoxicity offluazifop-butyl. Haloxyfop-methyle and sethoxydim. Weed Sci. 5 (32) : 574-583.

Haitas, V.C. ; E. Kotoula-Syka and I.G. Eleftherohorinos (1995) . Influence of propaquizafop application rate and time on Sorghum halepense (L.) Pers. control and cotton (Gossypium hirsutum) yield. Weed Research 35 (1): 1-6 .

Kurtz, M.E. (1986) . Control of Sorghum halepense (L.) Pers. in cotton with postemergence herbicides and trifluralin . Weed Research 26 (2): 83-88 . 